\title{
本明川延伸区間における夏季の 水温変化とその数値解析 \\ WATER TEMPERATURE CHANGES AT HONMYO RIVER IN SUMMER AND ITS NUMERICAL SIMULATION
}

\author{
西田 涉 1 ・鈴木誠二2 \\ Wataru NISHIDA and Seiji SUZUKI \\ 1正会員 博士(工) 長崎大学准教授 工学部社会開発工学科（†852-8521 長崎県長崎市文教町1-14） \\ 2正会員 博士(工) 長崎大学助教 工学部社会開発工学科（†852-8521 長崎県長崎市文教町1-14）
}

\begin{abstract}
Temporal and spatial variation of water temperature has predominant effects on physical transport processes and biological and chemical transformations of substances in water area. Consequently, adequate understanding of water temperature changes is important facet of water quality management.

In this study, field observations were carried out at the downstream reach of Honmyo River located at northern part of Isahaya Regulation pond. Furthermore numerical model for simulating water temperature changes was proposed and applied to this water area. Observed results show that thermal stratification is diurnally developed during dry weather condition. Redevelopment of the stratification after its dissipation due to the inflow of flood is subjected to temporal variation of wind speed. Although there is a room to tune the model parameters, proposed model simulates the observed results with acceptable error. Computed results show that thermal stratification is developed in all computed region. During the redevelopment of stratification, it takes a few days to raise water temperature in deeper layers.
\end{abstract}

Key Words : water temperature, stratification, field observation, numerical simulation model, Honmyo River

\section{1. はじめに}

水域における水温の時空間変化は, 成層の形成要因や 生物活動の制限因子となり，水域内部の物質循環に物理 学的，生物学的等の側面功影響を与えることから，水 環境の変化機構を明らかにする上で水温変化の把握が欠 かせない. 本研究で対象と寸る本明川延伸区間は，2008 (平成20) 年の延伸告示によって一級河川本明川の河道に 指定された区間であり, 諫早湾干拓調整池の北部承水路 に相当する. そのため，当区間のとくに下流側の水質は， 調整池の水質に影響されやすい状況にある。.また，本明 川は延伸前の時点において調整池流域面積の約 $35 \%$ 占 め, 流域人口の $65 \%$ に相当する諫早市を貫流することか ら, 流域での人間活動に由来した污濁負荷を調整池にも たらす主たる河川とみられており ${ }^{1)}$ ，この延伸区間にお ける物質流動の把握は，調整池の水質変化に及ぼす外部 負荷の影響を明らかにする上でも重要である.

ところで, 諫早湾干拓調整池を対象にした水質解析に
ついては, 鉛直方向に単層としたモデルの適用事例があ る24).これは, 当水域の管理水位時における平均水深が $1.2 \mathrm{~m}$ 程度 $($ 最深部 $3 \mathrm{~m})$ であり, また, 数ケ月から数年間 といった長期的な水質の変化予測に対応した手法としな ければならないためである。 その一方で，著者らが延伸 区間で実施した無降雨期間における水温の観測結果から は，夏季に日成層が現れ，冬季については昼間に正列状 態，夜間には逆列状態の水温成層が形成されることが予 測された ${ }^{5}$. これらの現象は, 潮受堤からの海水浸透に よる塩分供給4)や䀣濁物質濃度が高いために透過日射量 の鉛直方向の減衰が大きい等の理由によって，当区間内 に塩分と水温の多重成層が形成されることで生じたもの と考えている. 比較的浅い水域においても日成層の形成 が流れや水質の変化に無視できない影響を与える場合が あることりを考慮すると，この延伸区間の水質変化機構 の把握には, 水温の時空間変化を明らかにする必要があ り，成層の形成による物質輸送の変化を考慮し得るモデ ルを用いた解析が望ましいと思われる.

本研究では，夏季における水温の時空間変化の把握を 
目的として本明川延伸区間において現地観測を行った. また，昨年度の冬季と夏季の観測結果を用いて水温変化 の数值予測モデルの適用性を検証すると共に，夏季降雨 流入後の水温の変化過程を予測, 評価した.

\section{2. 現地観測の概要と水温変化}

\section{（1）観測の概要}

本明川延伸区間は図-1に示寸諫早湾干拓調整池の北部 水域であり，旧河口から下流端である北部排水門までの 流路延長は約 $6.9 \mathrm{~km}$ である。現地観測は3回 (観測期間 I : 2010 (平成22) 年7月 2日 9日, 観測期間 II : 同年7 月23日～8月 6日，観測期間III：同年8月 6日～27日) 実施 された. 観測期間 I，II は流下方向の水温変化を把握す ることを目的とし，延伸区間の上流部と中央部の二箇所 (地点(1), 地点(2) を観測地点とし, 水深0.8mまでの水温 を連続測定した. 観測期間IIIでは, 中央部 (地点 (1) に おける中層部 (水深 $1.35 \mathrm{~m}$ ) までの水温を連続観測して いる．測定時間間隔はいずれの期間も 1 時間である．次 節に示寸降雨量，風速，全天日射量，気温の值は，気象 庁長崎海洋気象台の報告值》を参照している.

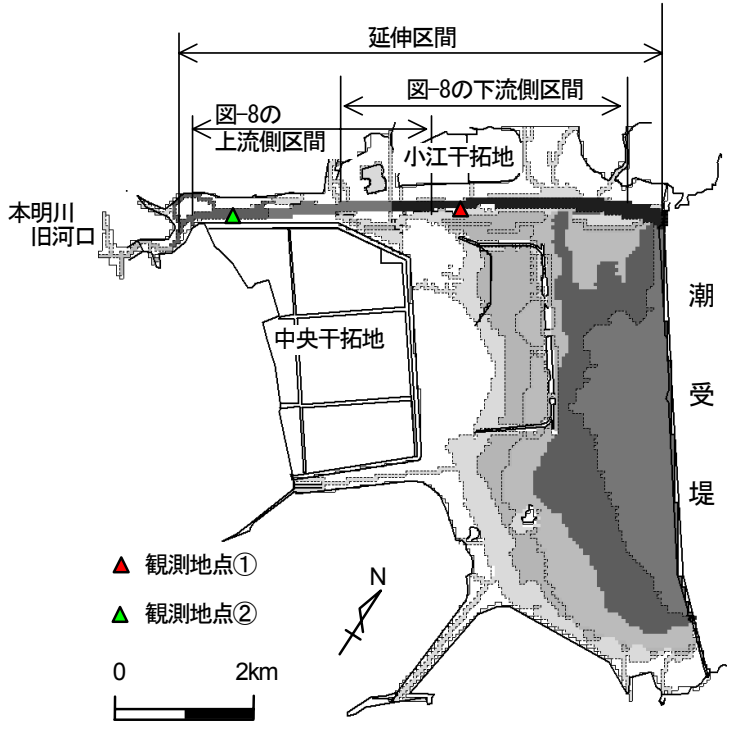

図-1＼cjkstart本明川延伸区間と観測地点

\section{（2）水温の時間変化}

まず，観測期間 I，IIにおける気象諸量と，測定地点 (1), (2)で測定された水深 $0.1 \mathrm{~m}$ での水温, 水深 $0.1 \mathrm{~m}$ と水深 $0.8 \mathrm{~m}$ の水温 $\left(\mathrm{T}_{0.1}, \mathrm{~T}_{0.8}\right)$ との水温差 $\left(\mathrm{T}_{0.1}-\mathrm{T}_{0.8}\right)$ の時間変化 を図-2,3に示寸。

図示した二回の観測期間には数回の降雨が観測されて おり，これに応じた水温の変化が見られる. とくに，7 月3日や4日，28日など比較的降水量が多い日には水温の 低下が顕著である.この変化については, 河川からの流 入水の水温に影響を受けると共に, 日中の降雨のために 雨雲等によって同日の直達日射量が減少した結果である
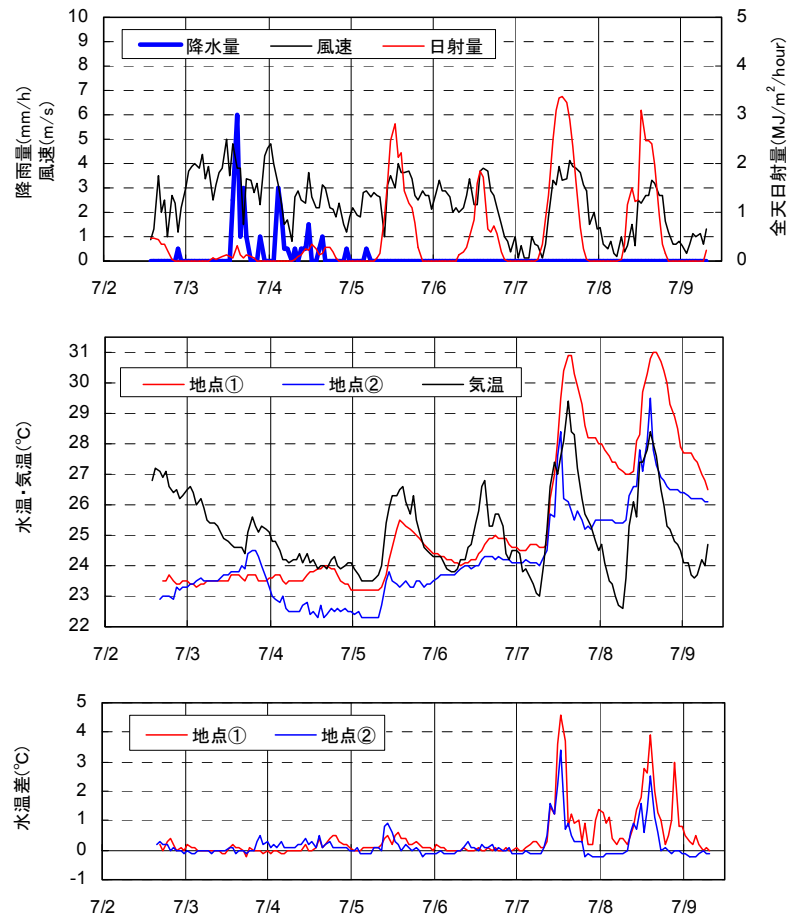

図-2 水温等の時間変化（観測期間 I )
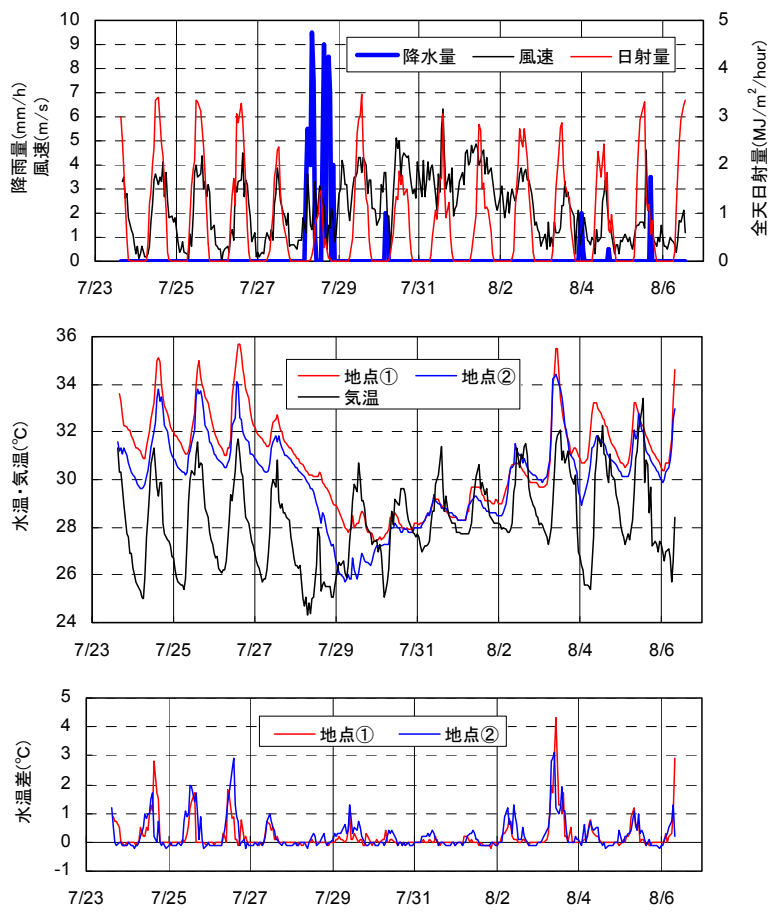

図-3 水温等の時間変化（観測期間 II）

と考えられる，一方，降雨が観測されなかった日の水温 には，昨年の観測結果と同様に，全天日射量の時間変化 に連動した日周期変化が現れており，7月23日〜27日の ように無降雨期間が継続すると，いずれの観測地点にお いても日夜をとおして大気温よりも $3^{\circ} \mathrm{C}$ 以上高い温度で 推移する. また，流路軸方向には，下流側の観測地点(1) の水温が高い，水温差については，無降雨日には日中に 最大となり，夜間には零，もしくは水表面側の温度が僅 
かに低くなる.これら日中の水温差の程度については, 測定前夜からの風速の時間変化と関連性が見られるよう である. 寸なわち，まとまった降雨日の後にあたる7月7 日までの期間や7月28日〜30日までの期間のように，一 日をとおして風速が $1 \mathrm{~m} / \mathrm{s}$ を回らない場合には水温差が 小さくなり，その一方で，日没から翌朝にかけて風速が $1 \mathrm{~m} / \mathrm{s}$ を回る状態が続くと, 昼間に $2,3 \mathrm{~m} / \mathrm{s}$ 以上の風が連 吹しても水温差が大きくなる傾向にある. このことにつ いて該当日の全天日射量と風速の時間変化を比較すると， 風速の増加は全天日射量のそれよりも遅れていることが 分かる. そのことから，この風速が増していない間の受 熱による水表面付近の水温上昇が密度の鋁直分布をもた らし，また，風応力による乱れが小さいために，

Richardson数が大きくなり, 熱の鉛直拡散を低減させた ことがこうした時間変化となる要因になったものと推察 される，夜間にも継続して風が吹く場合には，表層付近
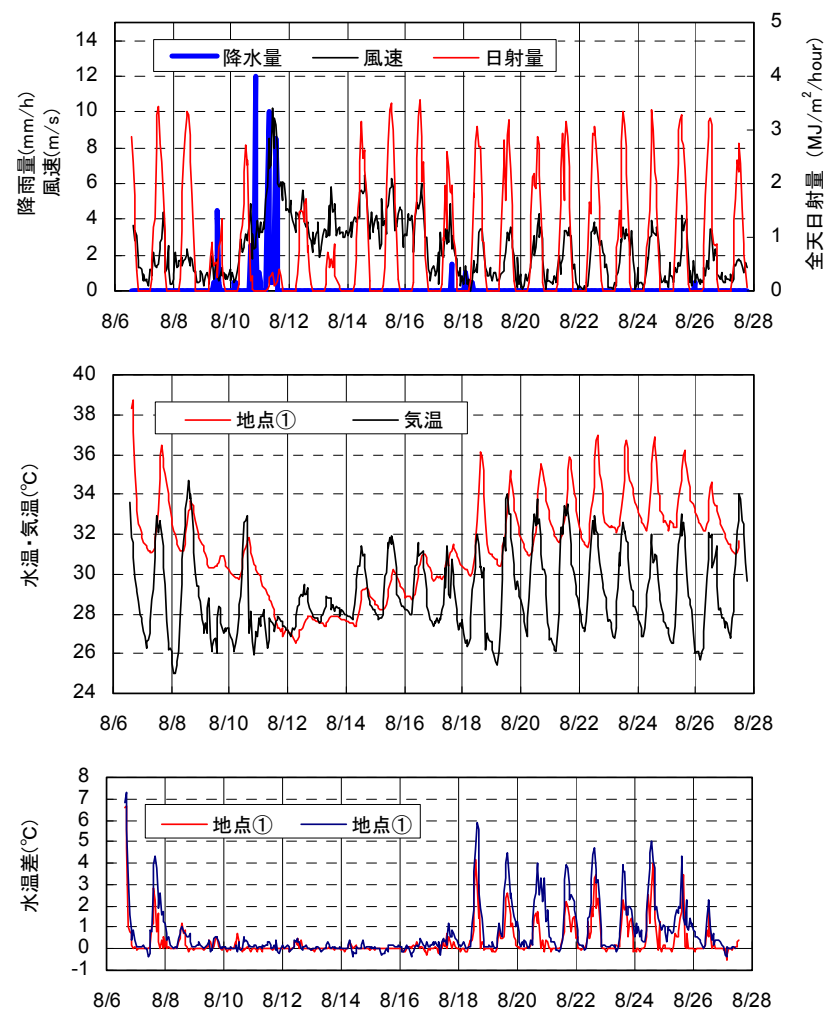

図-4 水温等の時間変化（観測期間亚）
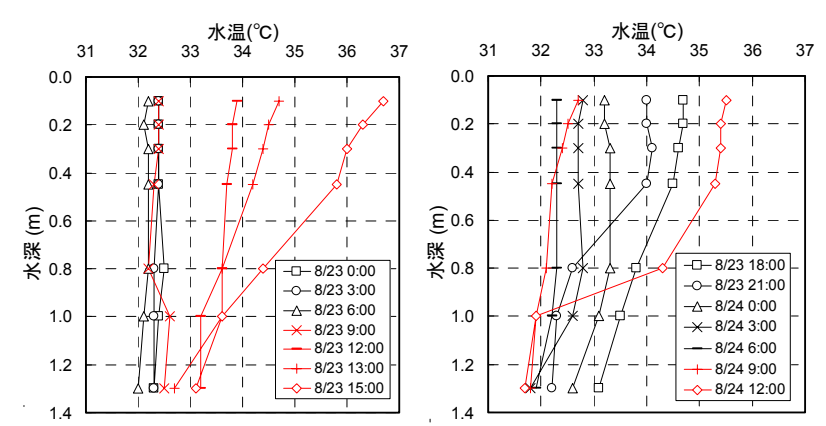

図-5 水温の鉛直分布

(2010(平成22) 年8月23日 0:00 8月24日 15:00)
での鉛直輸送が保たれ，先記の要因が形成され難かった ものと思われる.

つぎに，観測期間IIIにおける気象諸量と測定地点(1)で 測定された水温, 水温差 $\left(\mathrm{T}_{0.1}-\mathrm{T}_{0.8}, \mathrm{~T}_{0.1}-\mathrm{T}_{1.3}\right)$ を図-4に示す。 この期間に測定された水温の時間変化には，先述の考 察が適用できそうであり，8月10日や11日の降雨期間に は流入水の水温と日射量の減少によって水温が低下し， 風の連吹期間には水温差が小さい状態で水域の水温が上 昇している. その後, 風が日周期で変化する無降雨期間 に日最高水温がさらに高くなり, 水温差も大きくなると いった変化を呈している. ここで，8月23日からの数日 間の水温差を見ると, 水深 $0.8 \mathrm{~m}$ との差は明け方までに殆 どなくなるが，水深 $1.3 \mathrm{~m}$ との差が残留する結果となって いる．8月23日～24日正午までの水温の鉛直分布は図-5 のとおりであり, 水温の時間変化は表層側で大きく, 昼 間には水深 $0.6 \sim 1.0 \mathrm{~m}$ 付近に水温躍層が現れている. 夜 間の放熱時には，表層の温度低下に伴って一様分布に近 づくが，表層の一部には水温勾配が逆転することもある。 躍層の発生水深に関しては, 以前に行った観測結果に塩 分躍層が同等の水深で現れていたことから, 無降雨日が 継続したことで, 潮受堤堤体からの浸透や水底からの溶 出等 ${ }^{4}$ によって延伸区間の塩分の鉛直分布が再生したこ とも要因の一つと考えられる. 今回の観測では塩分等を 測定しておらず，水温の変化過程を明らかにするために も, これらの鉛直分布の実測が必要といえる.

\section{3. 水温変化の数値予測モデル}

\section{（1）数值モデルの概要}

流体運動に関する基礎方程式は連続方程式と運動方程 式であり，三次元レベルモデルとしてモデル化されてい る. 流水の密度は水温ならびに塩分と䀣濁粒子の濃度に 応じて変化するものとした，そのため，熱量と各成分の 収支式も基礎方程式に取り上げている. 運動方程式の渦 動粘性係数はPrandtlの混合距離モデルの形式で評価する. この内，鉛直方向成分については，成層の安定度によっ て変化するものとし, Richardson数の関数とした指数型 の評価式で算定している. 水表面に作用寸る風応力はバ ルク形式の表現とし，その抵抗係数については風速に応 じて変化するものとして取り扱った ${ }^{8)}$. 水底面での摩擦 応力にはManning則を適用した.

熱量の収支に関しては，表層での短波放射，大気・水 面からの長波放射，顕熱ならびに潜熱による熱輸送を取 り上げる．各成分はHuberらの方法”を基本として評価す るが，後述の観測結果との比較から大気の有効放射率を

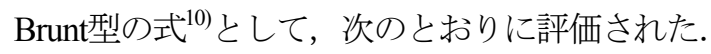

短波放射

$$
H_{S}=\beta(1-\alpha) H_{S 0}
$$


大気からの長波放射

$$
H_{L a}=\varepsilon_{a} \sigma T_{a}^{4}\left(1.0+0.17 C^{2}\right)
$$

水面からの長波放射

$$
H_{L w}=\varepsilon_{w} \sigma T_{w}{ }^{4}
$$

潜熱

$$
H_{E}=\rho\left(L+c T_{w}\right) f(W)\left(e_{w}-\psi e_{a}\right)
$$

顕熱

$$
H_{T}=B_{o} H_{E}
$$

ここに， $\alpha:(=0.03)$ アルベド, $\beta:(=0.3)$ 水表面におけ る短波放射の吸収率, $H_{S 0}$ : 全天日射量, $\sigma$ : StefanBoltzmann定数, $\varepsilon_{a}:\left(=a_{1}+a_{2} e_{a}^{1 / 2}\right)$ 晴天時の大気の有効放 射率 ( $a_{1}=0.7, a_{2}=0.037$ とした,$T_{a}$ : 大気温, $C$ : 雲量, $\varepsilon_{w}:(=0.97)$ 水の放射率, $T_{w}$ : 表層の水温, $\rho:$ 水の密度, $L$ : 蒸発の潜熱, $c$ : 水の比熱, $f(W)$ : 潜熱・顕熱輸送量 の水表面付近の風速 $(W)$ 一の依存性を表す関数 (ここ ではRohwerの式9,11) : $f(W)=0.000231+0.000139 a_{3} W$ とされ, これに補正係数 $a_{3}$ を含め, 計算結果と観測結果との比較 から $a_{3}=0.425$ とした), $e_{w}$ : 表層の水温に相当寸る飽和蒸 気圧, $e_{a}$ : 大気の蒸気圧, $\psi$ : 相対湿度, $B_{o}$ : Bowen比, である. Bowen比の乾湿計定数は $0.677 \mathrm{hPa} / \mathrm{K}$ とた ${ }^{12)}$. 水中を透過する短波放射の減衰はLambert-Beer則に従う ものとし，この減衰率は流水中の懸濁粒子濃度に比例す るとして取り扱った.

懸濁粒子については，前年度に延伸区間で行った測定 結果から，濁度の鉛直分布がRouse式でほぼ表現される ことが示されており, 浮遊砂モデルとして表現された. ここでは粒子の水底からの離脱をPick up rateで表現した ${ }^{13)}$. 粒子の沈降速度はRubeyの式で算定する。 なお，水 底一の着底には沈降限界を課し, 沈降速度が摩擦速度を 超える場合に生じるものとした．塩分に関しては，潮受 堤堤体からの浸透) と河川からの流入量を境界条件とし て考慮した．各基礎方程式は，時間軸方向にLeap-Frog 法を, 空間方向にはDonor Cell法と中央差分法を適用, 離散化している.

\section{（2）モデルの検証}

計算対象領域は，図-1に示寸本明川延伸区間と諌早湾 干拓調整池の全域である. 空間差分間隔は，水平方向に $\Delta x=\Delta y=50 \mathrm{~m}$ とし，鋁直方向には $\Delta z=0.1 \mathrm{~m}$ とした.この 検証計算では表層をT.P.-1.1m以浅とした．時間差分間 隔は $\Delta t=4.0 \mathrm{~s}$ である．流入河川として本明川を含む 13 本 を取り上げた. 気象条件に関しては，全天日射量，気温， 湿度を長崎海洋気象台の報告值とし，風向風速は気象庁 による当領域付近の数值予報值を与えた. 検証データと しては，モデルの季節的な適合性を確認する目的から， 2009 (平成21) 年の夏季と冬季の観測結果 (夏季期間 : 同年8月28日～9月 4日，冬季期間：12月18日～24日) を

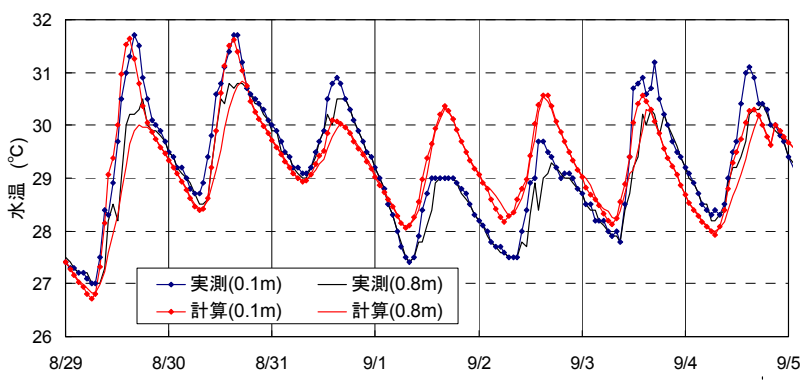

(a) 2009 (平成21) 年8月28日 9月4日

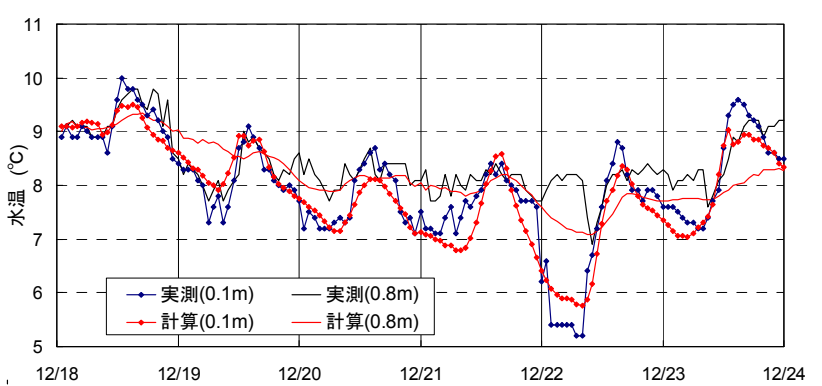

(b) 2009 (平成21) 年12月18 24日

図-6 水温の計算結果と観測結果

取り上げた。いずれも地点(1)での観測結果である.

図-6は各計算条件の下で得られた水温の計算結果と観 測結果との比較図である。なお，冬季期間の計算につい ては，全天日射量の報告值を用いると 18 日と21日の水温 が過小, 過大になるため, 各日の值を2倍と0.68倍とし ている. 各結果の比較から, 夏季期間では9月1日と2日, また冬季期間には 12 月 22 日以降の水深 $0.8 \mathrm{~m}$ での水温の算 出値の差が大きい. いずれも前日の日没からの水温低下 過程が十分に再現されなかったためと考えており, 顕 熱・潜熱等による水表面からの熱放射量と水中での熱輸 送の評価に検討の余地があるといえる. 一方で，夏季の 正列日成層と冬季における夜間の逆列成層の発達と昼間 の消滅が再現されており, 本モデルの構成によって両観 測期間における水温変化を概水計算できると思われる. 紙面の都合でここでは示していないが，当延伸区間の表 層と底層との塩分差は約 $0.5 \%$ (表層 $1 \%$ ) であった。この 鉛直分布を考慮しない解析では，とくに，冬季の結果で 水温の逆列が再現されておらず，塩分のモデル化の必要 性が改めて指摘されたものと考えている. 構築したモデ ルは，塩分と水温の分布に由来した成層の消長が現れる 河口域等での水温予測に有用と考える.

\section{4. 降雨後の水温と流れの予測計算}

\section{（1）計算条件}

対象期間としては，観測結果の考察から，降雨期間と 共に, 降雨後に風が連吹状態から日周期変化一遷移寸る までの期間を取り上げる必要があると考えられる．今回 の計算では，計算領域を細分化したことで計算に時間を 
要することから，風の日周期変化一の遷移日数が短い観 測期間 I (7月3日零時から6日間) を対象とすることにし た. 数值計算上の条件は前章(2) とほぼ同様であるが, 当水域の水位が観測前日の深夜からT.P.-1.3m程度まで 下げられていたことから ${ }^{14)}$ ，表層をT.P.-1.4m以浅に変更 した. 降雨時の河川流量は, 流出関数法を用いてその時 間変化を評価し，各河川に流域面積に応じて配分，基底 流量に上乗せした．流入水温は，上流側の地点(2)での観 測結果を参考に洪水時を $22^{\circ} \mathrm{C}$, それ以外を $24.5^{\circ} \mathrm{C}$ とた。 調整池加らの雨水排水は，資料 ${ }^{14)}$ から7月7日と8日の11 時に南北两排水門からなされるものとし，これらのゲー 卜開度を $1 \mathrm{~m} に$ 設定した.

\section{（2）水温の計算結果と考察}

図一位計算から得られた水温の時間変化を示す。この 結果を図中の観測結果と比較すると, 計算は前半期の地 点(1)の水温を $0.5 \sim 1^{\circ} \mathrm{C}$ 程度高めに評価する傾向にあり, 地点(2)の結果には7月7日と8日の日中に観測された表層 での低減は現れていない，これらは，モデルの検証で記 したように表層付近での熱収支に関連する係数值の設定 に起因するところが大きいと考えられる.さらに地点(2) の水深 $0.1 \mathrm{~m} の$ 急激な変化は, 排水門操作時刻に相当して おり，上流からの流出水温に影響されたことも予想され る. 一方で, 降雨日以降に水温の日変化が次第に大きく なり, 日を追って各地点の日最高水温が高くなる過程を

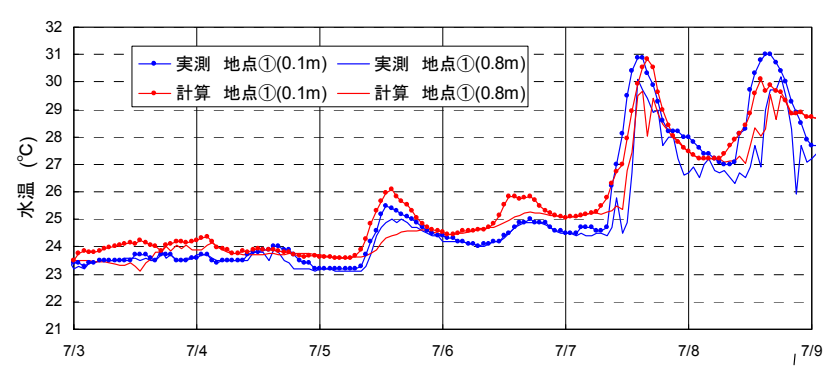

再現できていると考えられる.

ここで，7月4日と7日の14時における延伸区間の上流 側と下流側での水温の空間分布を示寸と図-8のとおりで ある. 表示区間は図-1に示されている. 各時刻には南西 からの風が吹いている，なお，延伸区間の法線は緩やか に湾曲しており，両区間は同一座標軸上で表示されない ため，上流側区間は下流側区間より $100 \mathrm{~m}$ 南側の断面の 結果を示している．まず，7月4日の結果については，計 算開始から表示時刻までに断続的な降雨 (累積雨量 $32 \mathrm{~mm}$ ) があったことで, 水位が既に $0.37 \mathrm{~m}$ 上昇している. この時刻には南西からの風が吹いていることもあり，表 層で東向きの流れであり, 中・底層では表層の流れを補 償するように西向きの流れが現れている. 水温に関して は，洪水時に各河口から低温の河川水が流入しており， 流域面積の最も大きい旧本明川からの流量が多いために, 延伸区間内の上流側において水温が低い．鉛直方向には， 表層で高くなる箇所もあるが，ほぼ一様分布となる.

つぎに，7月7日の結果では，短波放射等による熱供給 がなされたことで，当区間内の水温は全体的に上昇し， また，鋁直方向の空間変化が明瞭に現れる．表層では， 上流部で河川水の水温に影響されて低温であるが，水の 流下中の受熱によって次第に高温になり，下流側区間で は $28^{\circ} \mathrm{C}$ 以上となる. 潮受堤付近では, 風による水の吹き 寄せによって鉛直下向きの流れが発生するため, 表層水 が深層に輸送されることで中層以深の水温が高まる．た

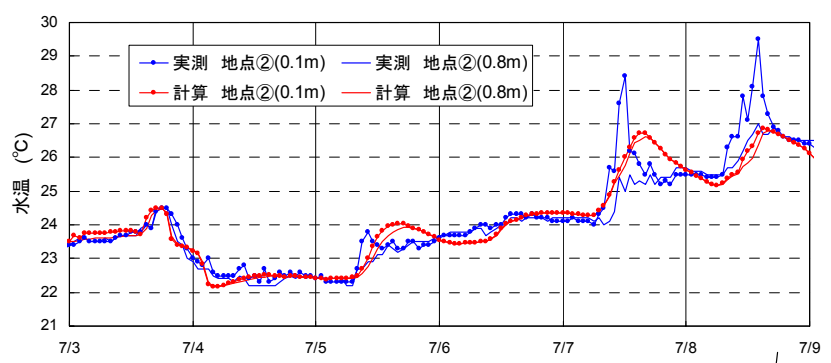

図-7 水温の計算結果と観測結果
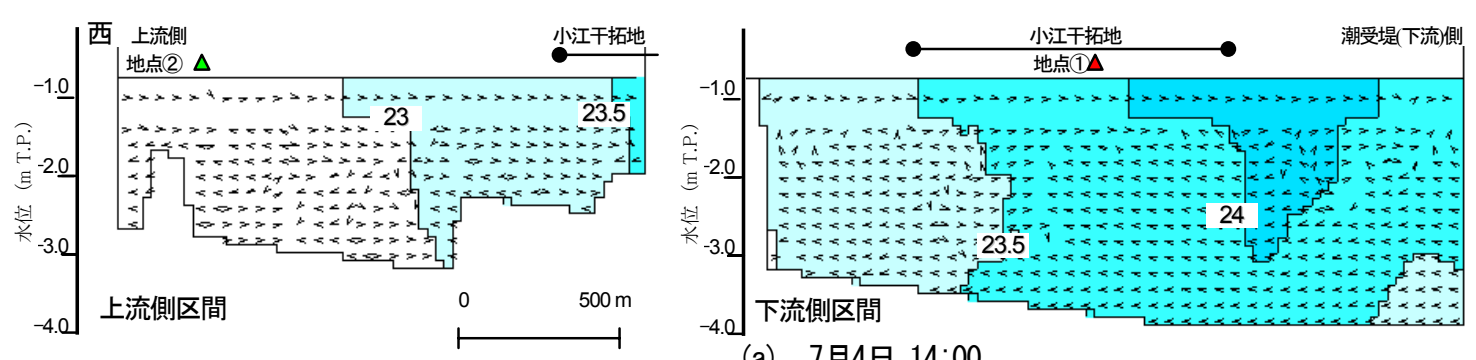

(a) 7月4日 14:00
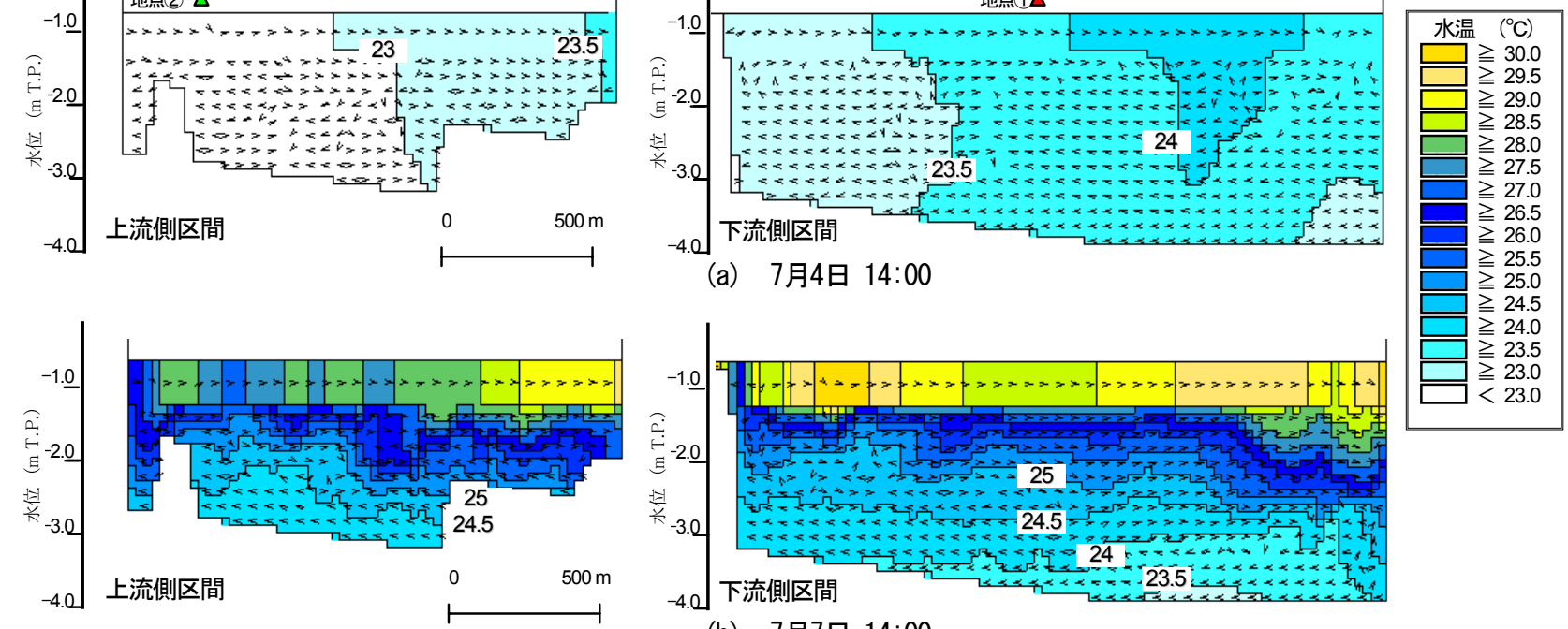

(b) 7月7日 14:00

図-8 延伸区間の水温の空間分布 


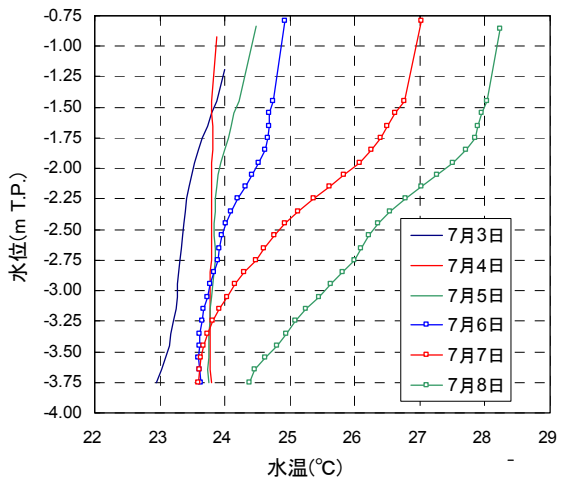

図-9 地点(1)の水温の計算結果

だし，こうした鉛直流による変化は潮受堤付近に限られ るようであり, 底層では洪水流入後程度の低水温の状態 が続くことが示されている。 これは，潮受堤付近を深層 へと潜った水隗には, 周囲との水温差による浮力効果が 生じるために水平方向への輸送がされ難くかったこと, また短波放射による熱供給量の観点からは，流水中の䀣 濁物質濃度が高いために短波放射の減衰率が大きく, 中 層以深への短波放射の到達量が小さいこと等が原因とし て上げられる．水温の鉛直分布について，地点(1)たお る日平均值の計算結果を示寸と図-9のとおりである. 水 温は，前日から当日にかけて降雨が観測された7月4日に ほぼ一様な状態であり, その後, 水深約 $1.25 \mathrm{~m}$ ま゙の表 層から水温が上昇し始める. 下層側の変化は上層よりも 遅れて現れており，この計算条件では，水温が上昇する までに3日間以上を要し，7月7日の上下層間の水温差は $3.4^{\circ} \mathrm{C}$ 以上に達寸る結果となっている.

\section{6. おわりに}

本研究では，諫早湾干拓調整池の一部である本明川延 伸区間において現地観測を実施し，夏季における水温変 化の実態把握を試みた. また, 数值予測モデルの検証と 夏季降雨後の水温変化過程への適用を行った.

連続観測の結果から，観測地点では，無降雨日に水温 の正列成層が日周期で現れるものの，水温成層の程度は 風の時間変化にも影響され，無降雨日であっても降雨後 の数日間のように風が1日をとおして翌朝まで連吹する 場合，水温の鉛直変化が弱まることが示された. 各地点 における降雨後の水温成層の発達については, 限られた 観測結果に基づくが，風の連吹期とその日周期への遷移 から推定できるものと思われる. 数值予測モデルに関し ては，夏季と冬季の水温の日変化，さらに降雨後の変化 過程を概ね再現しており，モデル化は妥当になされてい ると考えている. 降雨後を対象にした計算として，観測 結果 I の条件下で得られた結果から，降雨の流入によっ て，河道法線方向の分布はあるが，当延伸区間の水温は 鉛直方向にほぼ一様になることが示された．その後の短
波放射等の熱供給によって水温が全体的に上昇するもの の，底層部では表層に比べて数日間の遅れを生じること が予測された. 今回，現地観測と数值予測モデルの妥当 性の検証は，本明川延伸区間の上・中流部を対象に行っ ているが，同区間の水温変化の全体像を明らかにするに は，さらに下流部や調整池側での観測結果による検討も 必要と考えている. 数值モデルに関しては, 他の観測結 果一の適用等をとおしてパラメータ值の推定を図ると共 に，水質污濁物質のモデル化を行い，当水域における水 質変化機構の評価へと繋げたい.

謝辞 : 連続観測を実施するにあたって，装置の設置や データの回収に協力頂いた学部4年生の山口慶直氏, 岩 尾良太朗氏，池永雄太氏に感謝申し上げます。

\section{参考文献}

1) 浦 里実, 野口正人, 㴊上雄作 : 閉鎖性水域一流出する污 濁量の削減方策の検討 諫早湾調整池とその流域, 水工学論 文集, Vol.49, pp.1549-1554, 2005.

2) 古賀憲一, Vongthanasunthorn Narumol, 荒木宏之, 山西博 幸, 川邊 学, 大和則夫 : 諫早干拓調整池の水質解析, 環境 工学研究論文集, Vol.40, pp.541-550, 2003.

3) 仁木将人, 西田 渉, 野口正人, 橋本篤史 : 諌早調整池に おける水質変化の予測とその評価に関寸る研究，水工学論文 集, Vol.43,pp.1007-1012, 1999.

4) 細谷裕士, 横井 績, 富田友幸, 矢永純一, 梶原義範: 諫 早湾干拓調整池一の海水導入による水質への影響, 水環境学 会誌, Vol.27, No.4, pp.281-286, 2004.

5) 西田 渉, 鈴木誠二 : 本明川延伸区間における夏季・冬季 の水温変化とその数值予測に関する研究, 環境工学研究論文 集, Vol.47, pp.49-56, 2010.

6) 石川忠晴, 田中昌宏, 小関昌信 : 浅い湖の日成層が水質に 及ぼす影響，土木学会論文集，No.411/II-12,pp.247-254, 1989.

7) 気像庁ホームページ資料(URL http://www.jma.go.jp/)

8) 近藤純正 : 水環境の気象学, 朝倉書店, pp. 168-174, 1994.

9) Huber C. H., and Harleman D. R. F. : Laboratory and analytical studies of the thermal stratification of reservoirs, Hydrodynamics laboratory MIT, R68-87, Rept. No.112, pp.16-34, 1968.

10) Anderson, E.R. : Energy-budget studies, U.S.G.S. Professional Paper, No.269, pp.71-119, 1954.

11) Rohwer, C. : Evaporation from a Free Water Surface, U.S. Dept. of Agr., Tech. Bull. No.271, p.96, 1931.

12) 前出 文献8), pp.132-138, 1994.

13) 村上正吾, 辻本哲郎, 中川博次 : 河床砂碟のPick-up rateの 推定式について，土木学会論文集，No.443/II-18,pp.9-16, 1992. 14) 国土交通省ホームページ資料 (URL http://wwwl.river.go.jp/)

(2010. 9. 30受付) 